\title{
IMMUNOHISTOCHEMICAL STUDIES OF S-100 PROTEIN DURING POSTNATAL ONTOGENESIS OF THE BRAIN OF TWO STRAINS OF RATS
}

\author{
S. M. Sviridov, L. I. Korochioin, V. N. Ivanov, E. I. Maletskaya and \\ T. K. BAKHTINA
}

Laboratory of Developmental Genetics and Laboratory of Evolutional Genetics of the Institute of Cytology and Genetics, Siberian Department, Acad. Sci. USSR, Novosibirsk-90

(Revision received 24 September 1971. Accepted 8 October 1971)

\begin{abstract}
We have studied the dynamics of the appearance of cells reacting positively with anti-S-100 protein antiserum, during postnatal neurocytogenesis in the brain of rats of two strains differing in their susceptibility to sound stimuli. The postnatal time of appearance of cells reacting positively with anti-S-100 protein antiserum was somewhat later in rats susceptible to sound-induced seizures than in sound-resistant rats. These differences concerned mainly the cerebral cortex of 12-day-old rats. By day 21 of postnatal life these differences had disappeared. In subcortical structures of the brain, S-100 protein was first found on the 4th to the 5th day of life and the rate of appearance of cells containing this protein was similar in the two strains.
\end{abstract}

IT wAS established earlier that postnatal neurocytogenesis is accompanied by appearance of five organ-specific antigens in the rat brain (SviRIDOv and PolyaKova, 1969; Sviridov, KorochKIN and Polyakova, 1970). One of them, the S-100 protein, has been isolated by MOORE (1965) in pure form. Its characteristic properties are migration to the extreme anodal position during electrophoresis at $\mathrm{pH} 8 \cdot 0-9 \cdot 0$ and solubility in saturated ammonium sulphate at $\mathrm{pH} 7 \cdot 2$. According to MOORE, PEREZ and GeHRING (1968), the highest content of this protein is found in the molecular layer of the cerebellum. Cicero, Cowan, MOORE and Suntzeff (1970) have shown that the amount of S-100 protein is somewhat higher in thalamic regions undergoing retrograde degeneration and supposed that it was a glial protein. Studying the neuronal nuclear proteins by means of polyacrylamide gel electrophoresis, DRAVID and BURDMAN (1968) did not find any S-100 protein. HYDEN and MCEwEN (1966) used the fluorescent antibody technique to establish that specific fluorescence with anti-S-10C antiserum is found in the cytoplasm of glial cells and that the nuclei of large neurons also showed a distinct reaction with anti-S-100 antiserum. By the Coons technique, an increased content of S-100 protein in the hippocampal neurons of rats undergoing training was shown (HYDÉN and LANGE, 1970).

The specific function of the S-100 protein is not known. The experiments of MACEWEN and HYDÉN (1966) suggested a high metabolic rate of S-100 protein. However, these data were not confirmed by CICERo and MOORE (1970) who have shown that the half-life of S-100 protein is 15 days. MOORE (1969) showed, by means of the complement fixation reaction with anti-S-100 antiserum, that this protein is absent from the brain of new-born rats. It begins to appear on the 12-15 days of postnatal development and subsequently the content of this protein reaches 120 $\mu \mathrm{g} / \mathrm{g}$ of crude brain tissue by 60-80 days of life. ZuCKERMAN, HERSCHMAN and LEVINE (1970) demonstrated by means of microcomplement fixation with S-100 antiserum, 
that the first appearance of S-100 protein in human frontal cerebral cortex coincides with the appearance of electrical activity in this brain area. During the embryonic development of human brain, there is a caudo-rostral progression in the appearance of S-100 protein.

The aim of our present work was to study the distribution of S-100 protein in the cell population of the brain of two strains of rats during postnatal ontogenesis. In previous studies we have shown that animals of these strains differ in the rates of protein differentiation in the brain. Thus, in rats with audiogenic epilepsy the rate of appearance of water-soluble organ-specific antigens and isoenzymes of the esterases of the brain is somewhat delayed. The formation of the spectrum of the organ-specific antigens in rats with audiogenic epilepsy is over by postnatal day 17 , and in the animals resistant to audiogenic epilepsy it is over by day 14 (SvIRIDov et al., 1970; SvIRIDov, Korochkin, Polyakova and Matveeva, 1971). It was also shown that the last watersoluble organ-specific protein appearing in the course of postnatal brain differentiation is $\mathrm{S}-100$ protein. We decided therefore to identify the cellular components of the brain responsible for this 'delay' phenomenon. S-100 protein was chosen for the following reasons: first, it is the most amply studied organ-specific protein of the brain; secondly, it is easily identified during electrophoresis in polyacrilamide gel; thirdly, S-100 is relatively easy to isolate in a pure form.

\section{MATERIALS AND METHODS}

Rats of two strains-sound-susceptible and sound-resistant bred at Moscow University by Prof. L. V. Krushinsky and L. N. Molodkina (KM strain) from the Wistar strain (KRUSHINSKY, 1960) were used in the experiments. Rats of the KM strain react to the sound of an electric bell with convulsions. Selective breeding among the most sound-susceptible rats resulted in a sharp increase in both the percentage of susceptible animals and the degree of pathological hyperactivity in a few generations. The effectiveness of the selection indicates the hereditary nature of this derangement of the C.N.S. According to IoLKIN (1969), the predisposition to sound-induced seizures is inherited as an autosomal recessive characteristic. However, data suggest a more complicated mode of inheritance (KRUSHINSKY, MolodkINA and RoMANOVA, 1968). In a total of 36 animals, the following groups of both strains were studied: new-born, 5, 7, 15, 21 days old and adult.

Isolation of the $S-100$ protein. The S-100 protein was isolated from the water-soluble brain extract of Wistar rats in two stages: (1) Preparative electrophoresis in agarose gel. The electrophoresis was carried out in an agarose block $(18 \times 13 \times 1 \mathrm{~cm})$, prepared on veronal-medinal buffer $(\mathrm{pH} 8.6$; $I=0.025) ; 10 \mathrm{ml}$ of $12-10$ per cent water-soluble proteins of the rat brain were applied to the initial trench. The proteins were dialysed against gel buffer. The samples were subjected to electrophoresis at $140 \mathrm{~mA}$ and $100 \mathrm{~V}$ for $5 \mathrm{~h}$ under a layer of petroleum ether at $4^{\circ} \mathrm{C}$. The anodal portion of the gel was cut out and the protein was eluted by freezing (Tsverkov, 1968). The isolated crude protein fraction contained, beside a rapidly migrating component, some contamination with albumin.

(2) Preparative electrophoresis in polyacrylamide gel. The electrophoresis was carried out in a chamber as described by HJERTEN, IERSTERD and TISELIUS (1969) in a discontinuous system of buffers: 12 per cent $(\mathrm{w} / \mathrm{w})$ polyacrylamide gel on $0.05 \mathrm{M}$-tris-EDTA- $\mathrm{H}_{3} \mathrm{BO}_{3}(\mathrm{pH} 8 \cdot 6)$; the electrode vessels contained $0.3 \mathrm{M}-\mathrm{NaOH}-\mathrm{H}_{3} \mathrm{BO}_{3}$ buffer $(\mathrm{pH} 8 \cdot 3$ ). Electrophoretic separation of the proteins was carried out at $4^{\circ} \mathrm{C}$ for $18 \mathrm{~h}$. In the process of elution of protein from the polyacrylamide, the first anodal protein fraction corresponding to pure S-100 protein was collected. Under the indicated conditions for electrophoresis of the water-soluble extracts from the rat brain in agarose gel, S-100 protein migrates to the prealbumin zone of the electropherograms (Fig. 1). For this reason the gel block (pre-albumin zone) often contains serum albumin and this was recorded during immunoelectrophoresis with antiserum to the proteins of rat sera. It seems that contamination of the pre-albumin fraction by albumin is due to the high concentration of albumin applied to the initial trench $(1 \mathrm{~g})$. In the second stage of purification (electrophoresis in polyacrilamide gel), it is very easy to remove any albumin admixture, since in this case albumin lags considerably behind S-100 protein, not only because of its charge, but also in consequence of its high mol. wt. In both cases the isolation of protein was controlled by parallel analytical electrophoretic runs in 12 per cent $(w / w)$ polyacrylamide gel (DAVIS, 1964; ORNSTEIN, 1964). The mol. wt. of the protein was determined by means of Sephadex 


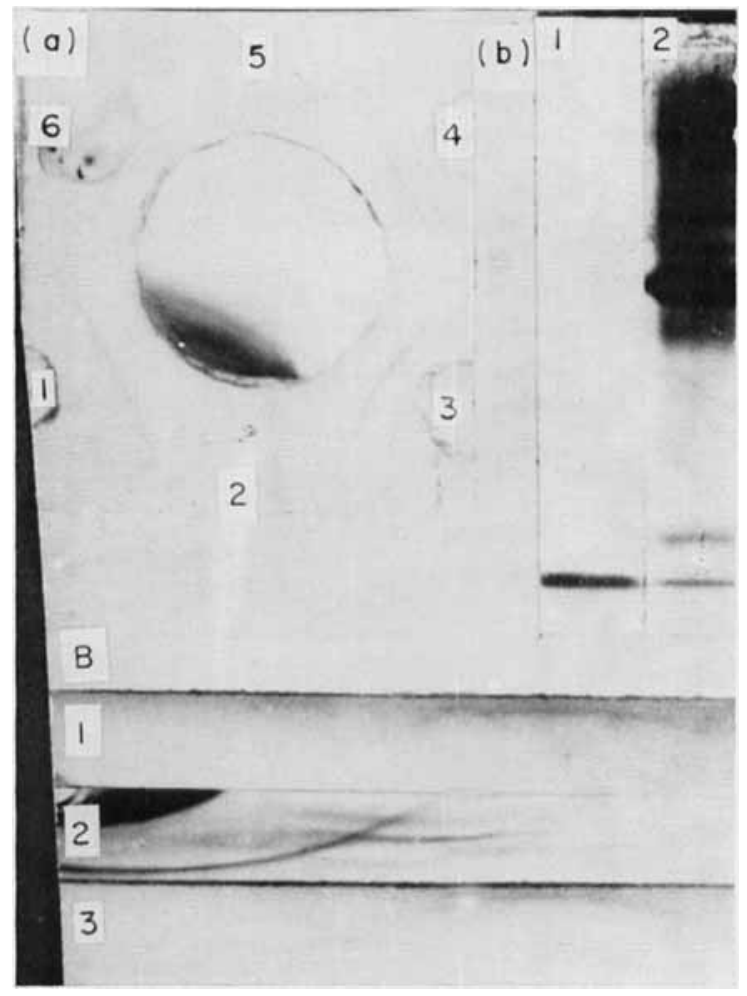

Fig. 1.-Immunological characteristics of the S-100 protein and antiserum preparations.

a. Control of anti-S-100 protein antibody specificity. In the central pit is the anti-S-100 protein antiserum.

1, S-100 protein; 2. rat serum; 3. rat brain extract; $4, \mathrm{~S}-100$ protein; 5 , total extract of heterologous rat organs; 6 , rat liver extract.

$b$. Electrophoresis in 12 per cent polyacrylamide gel.

1, S-100 protein; 2, rat brain extract.

B. Immunoelectrophoresis.

1, Rat brain extract. The immunoelectrophoretogram was developed with anti-S100 antiserum; 2, electrophoresis of rat brain extract. The immunoelectrophoretogram was developed with an organ-specific, anticerebral antiserum; 3, electrophoresis of $\mathrm{S}-100$ protein developed with anti-S-100 antiserum. 


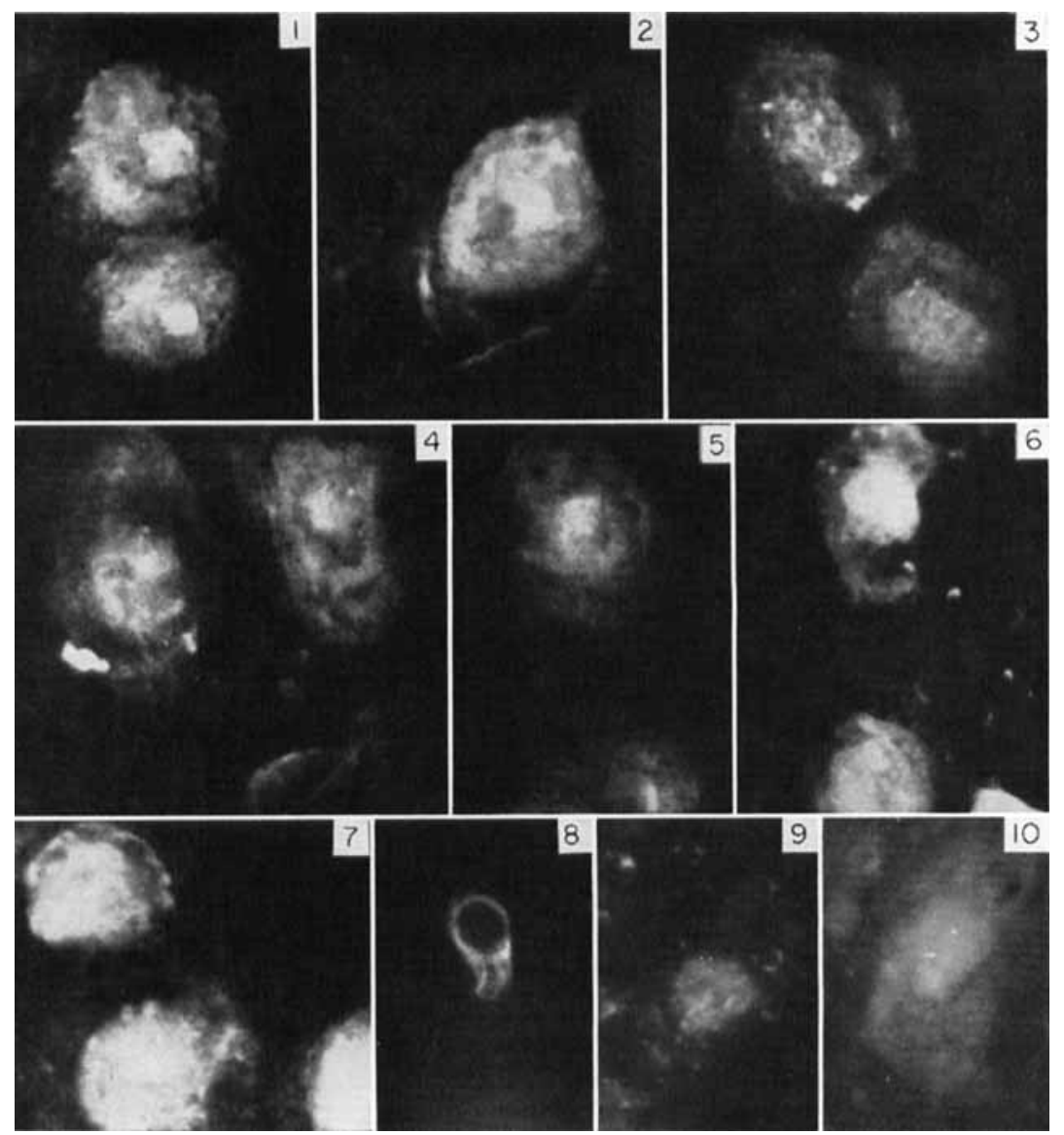

FIG. 2.-Sections of adult rat brain treated with specific anti-S-100 antiserum and developed with fluorescein-isothiocyanate-labelled donkey anti-rabbit serum. 1-7, nerve cells of the 5th layer of rat cerebral cortex treated with anti-S-100 antiserum prepared in the Institute of Cytology and Genetics, 8, a gliocyte detected by the same method; 9 and 10 , nerve cells of the 5 th layer of rat cerebral cortex treated with antiS-100 antiserum kindly sent by Dr. Levine (U.S.A.).

Note that in the nerve cells it is the nucleus that reacts positively with the anti-S-100 antiserum, and in the gliocyte it is the cytoplasm that is reactive. Photomicrograph ML-2, obj. 8, oc. $90 \mathrm{imm}$. 


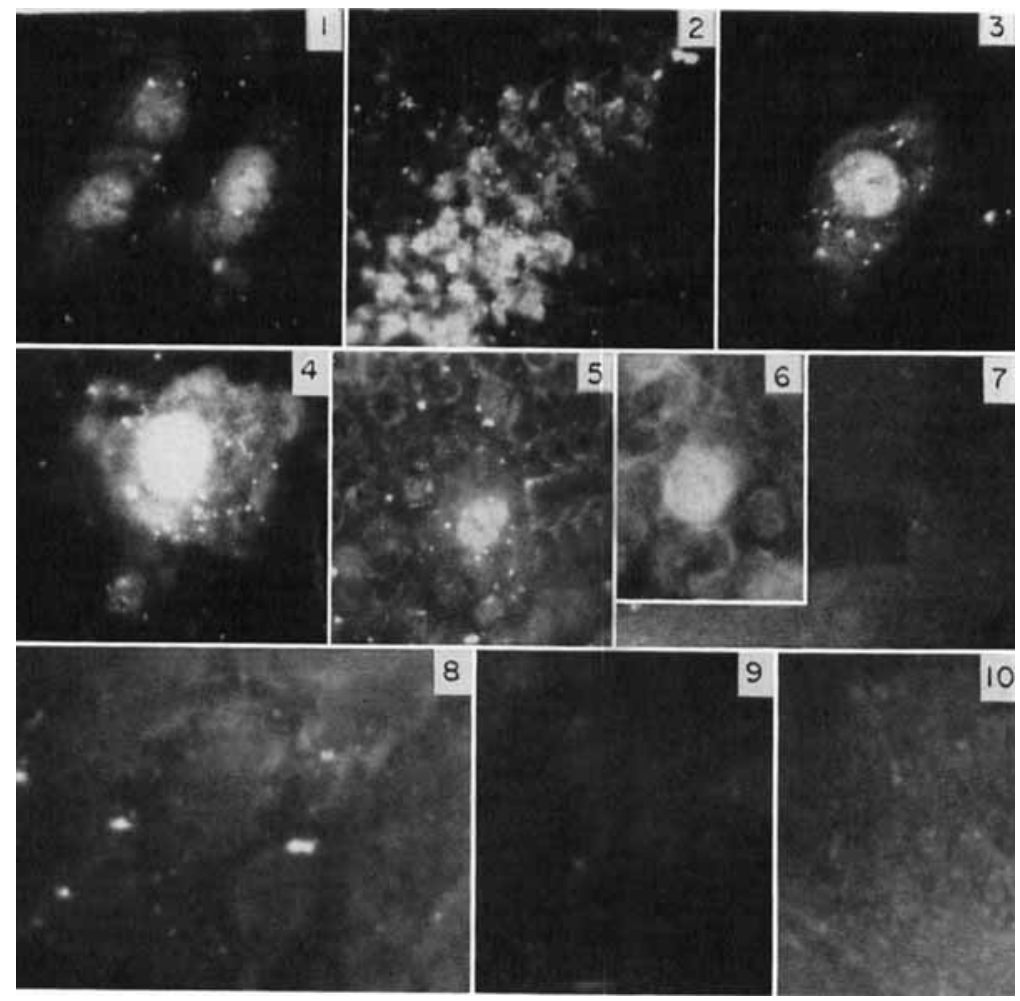

FIG. 3.-Immunohistochemical determination of S-100 protein in different organs and in different areas of nervous system of 21-day-old rats of sound-resistant ( $R$ ) and sound-susceptible strains (KM).

1 , the 5 th layer of cerebral cortex of a sound-resistant rat; 2 , hippocampus of a sound-susceptible rat (KM); 3-4, Deiter's nucleus neurons (KM); 5-6, Purkinje cells (KM); 7, lungs; 8, kidneys; 9, liver; 10, heart.

Photomicrograph ML 2. 1, 3, 5,6-obj. 5 oc. $90 \mathrm{imm}$.

2, 7-10-obj. 5 oc. 40 hydr. imm. 

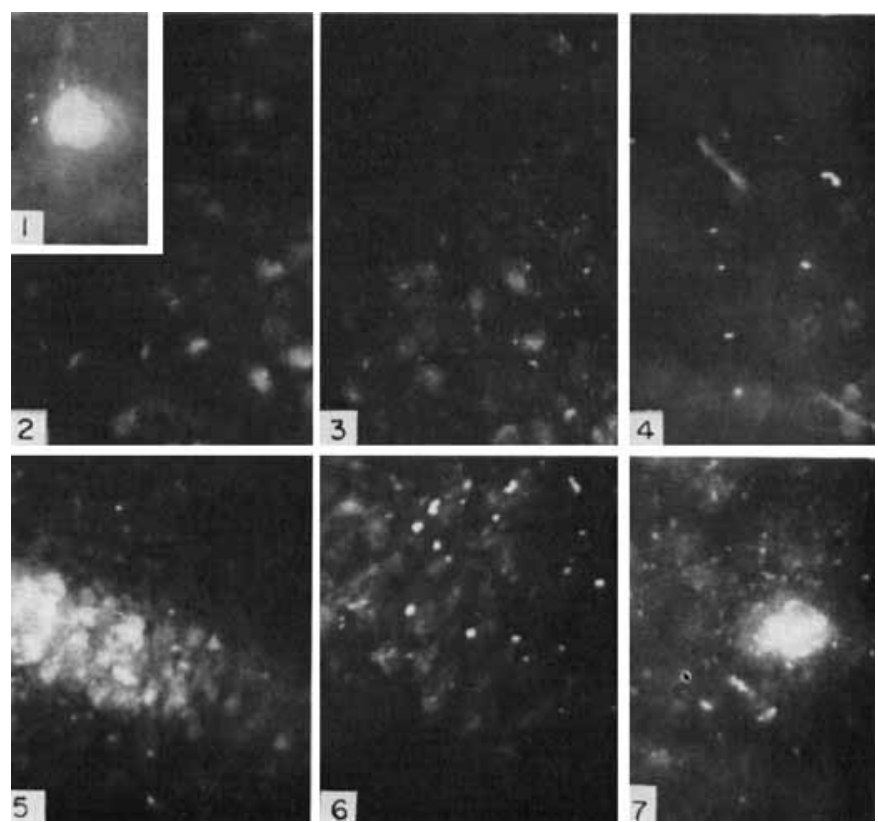

FIG. 4.-Immunohistochemical determination of $\mathrm{S}-100$ protein in nerve tissue of young (12-day-old) rats of the sound-resistant $(R)$ and sound-susceptible (KM) strains. 1, A cerebral cortical neuron of $\mathrm{R}$ strain; 2 and 3 , an $\mathrm{R}$ strain rat cerebral cortex; 4, a KM rat cerebral cortex; 5, an $\mathrm{R}$ rat hippocampus; 6, a KM rat hippocampus; 7, a Deiters nucleus neuron of KM rat.

Photomicrograph ML 2. 1,7-oc. 5, obj. $90 \mathrm{imm}$.

2-6, oc. 5 , obj. 40 hydr. imm. 


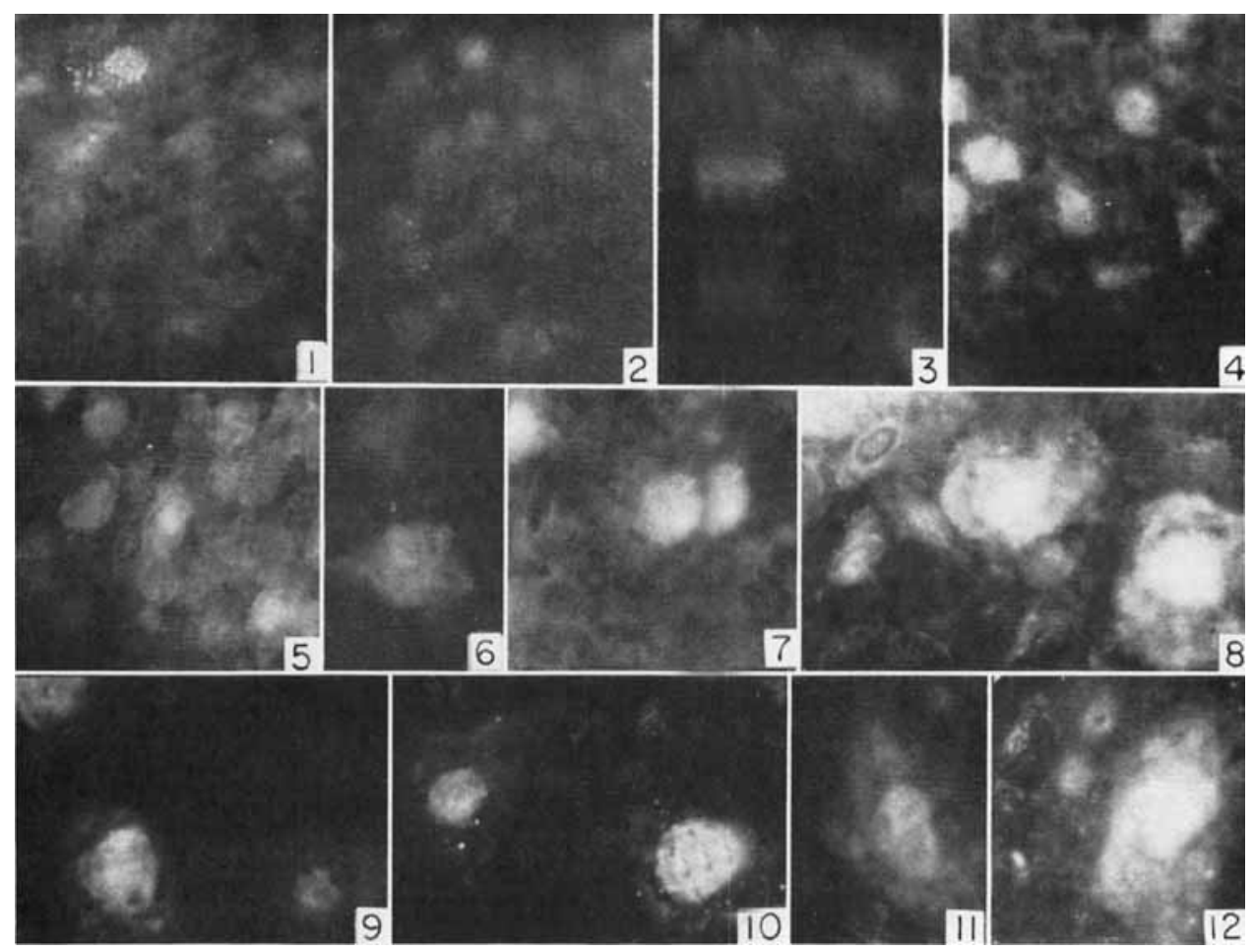

FIG. 5.-Immunohistochemical determination of S-100 protein in the brains of rats of different ages.

1-4 cerebral cortex; 1 , a newborn $\mathrm{KM}$ rat; 2 , newborn $\mathrm{R}$ strain; 3, 5-day-old $\mathrm{KM}$ rat; 4, R rat, 7 days old; 5 , hippocampus of an $\mathrm{R}$ strain newborn rat; 6 , Deiters' nucleus of a KM rat, 5 days old; 7, Deiters' nucleus, $\mathrm{R}$ strain, 5 days old; 8 , the same, $\mathrm{R}$ strain 7 days old; $9-10$, the same, $R$ strain 12 days old. 11 , Purkinje cells of 12-day-old $R$ rat; 12 , a neuron of the 5th layer of cerebral cortex ( $R$ strain).

Photomicrograph ML 2. 1-4 oc. 5 obj. 40 hydr. imm. The rest oc. 5 , obj. $90 \mathrm{imm}$. 
G-100 column chromatography, with $0.7 \times 70$ crn columns. The S-100 protein and the calibration proteins (bovine serum albumin, cytochrome $c$ were eluted with $0.05 \mathrm{M}$-tris $-0.14 \mathrm{~m}$-buffer $(\mathrm{pH} 7 \cdot 2$ ). The extinction of the resulting protein fractions was measured on an SFD-2 spectrophotometer at $280 \mathrm{~mm}$.

For mol. wt. determinations we used the empirical formula: $1 \mathrm{gM}=5,941-0,857(\mathrm{Ve} / \mathrm{Vo})$ (Determan, 1970), valid for Sephadex G-100, where M stands for mol. wt., Ve represents the volume of eluent in which the analysed polymer leaves the column (the point of maximum extinction on the chromatogram), and Vo represents the void volume of the column (equal to $26 \mathrm{ml}$ for the selected size of Sephadex G-100 column). Experimentally, it was established that the Ve of albumin is 33 $\mathrm{ml}$; Ve of cytochrome $c$ is $57 \mathrm{ml}$ and Ve of S-100 protein is $50 \mathrm{ml}$. When calculated, M for albumin $=69,000 ; \mathrm{M}$ for cytochrome $c=13,000 ; \mathrm{M}$ for $\mathrm{S}-100$ protein $=21,000$. The value obtained for the mol. wt. of the S-100 protein was considered to be valid because the marker proteins (cytochrome $c$ and albumin) were eluted from the same column with the calculated volume of buffer. Anti-S-100 antiserum was obtained from rabbits immunized with pure S-100 protein in combination with methylated bovine serum albumin, according to the technique of KESSLER, LEVINE and FASMAN (1968). Methylated bovine serum albumin was prepared by the method of SuEOKA and CHENG (1962). The specificity of the resulting antiserum was checked by double immunodiffusion in agarose with extracts from heterologous organs and with rat brain extract. The specificity of the antiserum was also checked by immunoelectrophoresis both with the aqueous extract from brain and with the pure S-100 protein.

Immunohistological analysis. Two variants of obtaining brain sections from the two strains of rats were used: (1) For the sections embedded in paraffin, the technique of SAINTE-MARIE (1962) was used. (2) Sections were also prepared in the cryostat from frozen brain tissue (PEARSE, 1962).

In our work we used the indirect fluorescent antibody technique (ENGELHARDT, 1968). Coronal sections $3 \mu \mathrm{m}$ thick through different regions of brain (sensorimotor cortex, dorsoventral hippocampus, Deiters' nucleus and cerebellum) were obtained by both the first and the second variants and were incubated with anti-S-100 antiserum. After washing in $0.14 \mathrm{M}-\mathrm{NaCl}(\mathrm{pH} 7 \cdot 2)$, anti-rabbit globulin donkey serum labelled with fluorescein isothiocyanate (N. F. Gamaleia Institute of Experimental Medicine) was applied onto the sections. The control sections were treated either with only labelled serum or with normal rabbit serum with subsequent combination with labelled donkey serum. Again, sections of heterologous organs (liver, kidney, spleen, lung and heart) served as controls; moreover, some of the sections were treated with anti-S-100 antiserum obtained from Dr. L. Levine (U.S.A.). The resulting preparations were embedded in buffered $(\mathrm{pH} \mathrm{7.2)} \mathrm{glycerine} \mathrm{and} \mathrm{studied} \mathrm{under} \mathrm{the}$ fluorescence microscope ML-2.

\section{RESULTS}

As illustrated in Fig. 1, the isolated protein migrated to the extreme anodal position in 12 per cent (w/w) polyacrylamide gel electrophoresis and the antiserum prepared against it gave only one precipitation band both with the isolated protein and with the aqueous band extract of rat brain. Immunodiffusion and immunofluorescence reactions with total aqueous extracts and sections of heterologous organs (liver, kidney, spleen and heart) were negative (Fig. 3 below). The mol. wt. determined by Sephadex G-100 column chromatography was 21,000 , a value which corresponds to the previously reported mol. wt. of S-100 protein (CALISSANO, MOORE and FrIESEN, 1969). The organ-specificity of the protein, its characteristic position on electropherogram and the data on mol. wt. measurement indicated that the isolated protein was most probably the S-100 protein (see Fig. 1). In immunoelectrophoresis, our specific anti-S-100 antiserum detected a rapidly migrating, organ-specific antigen in the water-soluble extract of the rat brain. (Fig. 1). Evaluation of the quality of our anti-S-100 antiserum was carried out by a comparison of preparations treated by it with those treated by anti-S-100 antiserum which had been kindly donated by Prof. L. Levine (U.S.A.). Practically identical results were obtained with both antisera (Fig. 2). We used both paraffin sections and frozen sections of fresh tissue obtained in a cryostat. The results with paraffin sections demonstrated more and the localization of protein could be determined more accurately-but for reproducibility, cryostate sections were better. 
Analysis of histological sections of the brain areas under study showed, in agreement with published results (HYDÉN and MCEwEN, 1966; HYDÉN and LANGE, 1970), a localization of the S-100 protein to the nuclei of neurons and to the cytoplasm of gliocytes (Fig. 2). This seems to be most marked in the cerebral cortex (Fig. 2). In the hippocampal pyramids, and especially in Purkinje cells of the cerebellum and in giant neurons of Deiters' nucleus, a weak luminescence on the periphery of the perikaryon can sometimes be seen (Fig. 3). Two types of distribution of the S-100 protein in neuron nuclei were observed: diffuse and more or less uniform (Figs. 2 and 4) and nonuniform distribution. In the latter case an intense luminescence of the nucleolus was often detected (Fig. 2). The concentration of the S-100 protein in glial cells seems to be rather high, since the luminescence of the narrow cytoplasmic zone around the nucleus of the gliocyte is very intense (Fig. 2).

We found no differences between adult rats of sound-resistant and sound-susceptible strains. However, we observed some peculiarities in the appearance of S-100 protein in the brains of these strains during postnatal ontogenesis. In both strains, in the brains of newborn animals no distinct luminescence was found (Fig. 5). Beginning with the 5th day of life, in the hippocampus and in the medulla oblongata and pons, in the nuclei of separate nerve cells and especially in the cytoplasm of gliocytes, there were some indications of luminescence above the background level. These phenomena were especially distinct in cells of the motor nuclei of the medulla oblongata. In the cerebral cortex, only very seldom were feebly luminescent cells found. On the 7 th and the 12th day of postnatal life in the above-mentioned areas of brain one could find clearly luminescent nuclei in the neurons and cytoplasm in the glia (Fig. 4). But such cells were few in number. At this period, clearly discerned heterogeneity of nerve cell populations seemed to develop, as expressed in asynchronous accumulation of the S-100 protein. By the 12 th day of life there were some differences between the sound-resistant and the sound-susceptible strains of rats. In the former, nuclei of neurons and glioplasm showed distinct luminescence; in the sound-susceptible strain there was no such luminescence; only occasional single cells with traces of luminescence were seen (Fig. 4). From the 21 st day, the intensity of luminescence in different zones of brain including the cerebral cortex in both strains began to level off.

\section{DISCUSSION}

As already mentioned, there are some data in the literature which provide evidence for the synthesis of S-100 protein during brain differentiation (MOORE, 1969; ZUCKERMAN et al., 1970). According to our previous immunoelectrophoretic data the S-100 protein is found primarily in the brain of sound-resistant strain on the 14th day of life and in the sound-susceptible strain on the 18th day (Sviridov et al., 1970). As one might expect, the more sensitive Coons method permitted us to detect the initial stages of accumulation of S-100 protein in the nerve tissue. In accord with biochemical data (ZUCKERMAN et al., 1970), there is a caudo-rostral progression of its appearance during ontogenesis, with onset at the 5th day of life. The increase of S-100 protein coincides temporally with the development of cell differentiation in rat brain (EAYRS and GoOdHEAD, 1959; KoROCHKIN and OlenefF, 1966). The period of accumulation of cells reacting positively with anti-S-100 antiserum in rat brain cortex is also characterized by a relatively synchronous polyploidization of pyramidal neurons of the 5 th 
cortical layer and by an intensification of RNA transport from the nucleus into the neuroplasm of these cells (RAUSCHENBACH and KOROCHKIN, 1971).

According to HeRschman, LeVINe and De Vellis (1971) quantifiable levels of S-100 protein are found in the brain stem of the rat on day 2 after birth and in the cerebrum on day 5 . The data we have obtained on the time of appearance of S-100 protein in the cerebrum are consistent with those reported by Herschman et al. (1971). It should be noted that at the cellular level S-100 protein is initially distinctly observed in the glial cells (from day 5) and only later (days 7-12) in the nuclei of the differentiating nerve cells. In the recent literature there is abundant evidence that S-100 protein is mainly located in the glial cells (BENDA, LightbODY, SATo, LeVINE and Sweet, 1968; Pfeiffer, Herschman, Lightbody and Sato 1970, Lightbody, Pfeiffer, Kornblith and Herschman, 1970; Herschman et al., 1971). On the other hand, HYDEN and MCEWEN (1966) have observed a nuclear localization of S-100 protein in the nerve cells in the immunohistochemical reaction of Coons. We have also found that S-100 protein has a nuclear localization in the neurons.

The discrepancies we have observed may be due to the presence of antigenic determinants similar to $S-100$ protein or modified S- 100 protein in the nuclear neurons, and to the marked leaching of protein S-100 out of the nuclear preparations of DRAVID and Burdman (1968). At first we suggested that the contradictory data on the localization of S-100 protein could be attributed to the specificity of the metabolism of S-100 protein, to its rapid disintegration in the nuclei of the neurons and to the related difficulties in its estimation when applying different biochemical procedures. However, the data, of HYDÉN and MCEWEN (1966) on the rapid metabolism of S-100 protein have not been confirmed. In more thorough experiments, CrCERo and MOORE (1970) have shown that the half-life of $\mathrm{S}-100$ protein is 15 days and, hence, it is rather stable. It should however, be admitted that the results of DRAVID and BURDMAN (1968) cannot entirely refute the observations made by HYDÉN and MCEWEN (1966) on the nuclear localization of S-100 in the nerve cells, for the isolation of nuclei is associated with a high probability of loss of different nuclear components, including S-100 protein. An example of protein loss during the isolation of nuclei may be the case of the loss of nuclear proteins, histones and RNA polymerase. In this connection the loss of S-100 protein by the nucleus appears quite possible due to its low mol. wt. and solubility in neutral saline solution.

Finally, as we have mentioned above, the first cells displaying a positive reaction with anti-S-100 serum in the course of postnatal development of the brain are gliocytes, and this seems to be evidence for the primarily glial origin of S-100 protein. This observation is in good agreement with the data in the literature (BENDA et al., 1968; Pfeiffer et al., 1970). As for the differences in the time of detection (both immunoelectrophoretically and by the Coons method) in the cerebral cortex of the rats of both strains, a number of other results have been obtained in our laboratory. In particular, by the technique of EDSTRÖM (1964) we have shown that in the soundresistant strain of rats the mean level of RNA in the neurons of Deiters' nucleus reaches the values characteristic of adult animals earlier than the sound-susceptible KM strain (by the 3rd week of life in the former and by the 3rd month in the latter). This phenomenon is related to the increase in the number of cells with higher RNA content (more than $500 \mathrm{pg}$ ) in the population of neurons in Deiters' nucleus. (MAXIMOVSKY, 1970; KoRochKIN, 1970). Furthermore, the development of the esterase 
isoenzyme pattern in the sound-resistant strain increases more rapidly than in KM (SVIRIDOV et al., 1971). Our results seem to provide evidence for the possibility of interstrain differences in the rate of biochemical maturation of the brain, as has already been noted by some authors (see KING, 1967) and which may represent the basis of development of interstrain differences in behavioural reactions.

Acknowledgements-The authors are sincerely grateful to Prof. L. Levine (U.S.A.) who has kindly donated some samples of anti-S-100 antiserum.

\section{REFERENCES}

Benda P., Lightbody J., Sato G., Levine L. and Sweet W. (1968) Science, N. Y, 161, 370.

Calissano P., MOore B. and Friesen H. (1969) Biochemistry, Easton 8, 4318.

CICERo T. and MOORe B. (1970) Science, N.Y. 169, 1333.

Cicero T., Cowan W., Moore B. and SuntzefF V. (1970) Brain Res. 18, 25.

Davis B. (1964) Ann. N.Y. Acad. Sci. 121, 404.

Determan H. (1970) Gel Chromatography p. 161. Nauka, Moscow.

Dravid A. R. and BuRdMan J. A. (1968) J. Neurochem. 15, 25.

EAYRS I. and GOODHEAD B. (1959) J. Anat. 93, 385.

EDSTRÖM J. (1964) In Methods in Cell Physiology (Edited by Prescott D.) p. 147. Academic Press, New York.

ENGELHARDT N. A. (1968) Immunochemical Analysis p. 165 Medicina, Moscow.

Herschman H., Levine L. and De Vellis J. (1971) J. Neurochem. 18, 629.

Huerten S., Iersterd S. and Tiselius A. (1969) Analyt. Biochem. 27, 108.

Hydén H. and Lange W. (1970) Expt. Cell Res. 62, 125.

Hydén H. and McEwen B. (1966) Proc. nat. Acad. Sci. U.S.A. 55, 354.

IOLKIN V. I. (1969) Behaviour Genetics p. 71. Nauka, Leningrad.

Kessler D., Levine L. and Fasman G. (1968) Biochemistry, Easton 7, 758.

KING J. (1967) In Behaviour-Genetics Analysis (Edited by HIRSCH I.) p. 22. McGraw-Hill, New York.

KoRochKIN L. I. and OlENEFF S. N. (1966) Usp. sovrem. Biol. 62, 77.

KoROCHKIN L. I. (1970) In Recent Advances in Anatomical Research in the USSR, IX International Congress of Anatomy (Edited by JDANOv D.) p. 53. Mir, Moscow.

KRUSHINSKy L. V. (1960) The Formation of the Animal's Behaviour Moscow University, Moscow.

Krushinsky L. V., Molodkina L. N. and Romanova L. G. (1968) Genetics and Pathology p. 168. Medicina, Moscow.

Lightbody J., Pfeiffer S., Kornalith P. and Herschman H. (1970) J. Neurobiol. 1, 411.

MCEWEN B. and HYDEN H. (1966) J. Neurochem. 13, 823.

MaXimovsky L. F. (1970) Ontogenes 1, 206.

MOORE B. W. (1965) Biochem. biophys. res. Commun. 19, 739.

Moore B. W. (1969) In Handbook of Neurochemistry (Edited by LAJTHA A.) Vol, 1, p. 93. Plenum Press, New York.

Moore B. W., Perez V. and Gehring M. (1968) J. Neurochem. 15, 265.

OrnStein L. (1964) Ann. N.Y. Acad. Sci. 121, 321.

Pearse A. (1960) Histochemistry, Theoretical and Applied. Churchill, London.

Pfeiffer S., Herschman H., Lightbody J. and Sato G. (1970) J. cell. comp. Physiol. 75, 329.

RAUSCHENBACH I. U. and KoROCHKIN L. I. (1971) Ontogenes In press.

SAINTE-MARIE G. I. (1962) J. Histochem. Cytochem. 10, 250.

SueokA N. and Cheng T. (1962) J. molec. Biol. 4, 161.

Sviridov S. M. and PolYakova E. (1969) Dokl. Acad. Nauk SSSR 187, 925.

SviRIDov S. M. KorochKin L. I. and Polyakova E. (1970) Ontogenes 1, 463.

Sviridov S. M. Korochkin L. I., Polyakova E. and Matveeva N. (1971) Biochem. Genetics 5, 379.

Tsvetrov V. S. (1968) Immunochemical Analysis p. 170. Medicina, Moscow.

Zuckerman J. E., Herschman H. R. and Levine L. (1970) J. Neurochem. 17, 247. 